\title{
A new priapulid assemblage from the early Cambrian Guanshan fossil Lagerstätte of SW China
}

\author{
Shixue Hu, Michael Steiner, Maoyan Zhu, Huilin luo, Angela ForChielli, \\ HELMUT KEUPP, FANGCHEN ZHAO \& QI LIU
}

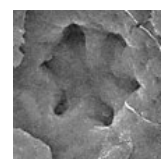

\begin{abstract}
A new priapulid assemblage, including 4 palaeoscolecidans and one corynetiid, is reported from the Guanshan fossil Lagerstätte (Cambrian Stage 4, Series 2) from East Yunnan, SW China. Three palaeoscolecidan new species, namely Yunnanoscolex magnus gen. et sp. nov., Wudingscolex sapushanensis gen. et sp. nov., Paramaotianshania zijunia gen. et sp. nov., and a new corynetiid species, Corynetis fortis sp. nov. are described. The lifestyles of these animals and their ecological significance are discussed. The occurrence of abundant and diverse priapulids from both the Chengjiang and Guanshan fossil Lagerstätten in East Yunnan indicates a possible radiation centre of this animal group on the soft-substratum shelf of the western part of the Yangtze Platform. $\bullet$ Key words: priapulids, Guanshan Lagerstätte, infauna, Cambrian Stage 4, China.
\end{abstract}

Hu, S.X., Steiner, M., Zhu, M.Y., LuO, H.L., Forchielli, A., Keupp, H., ZhaO, F.C. \& LiU, Q. 2012. A new priapulid assemblage from the early Cambrian Guanshan fossil Lagerstätte of SW China. Bulletin of Geosciences 87(1), 93-106 (6 figures). Czech Geological Survey, Prague. ISSN 1214-1119. Manuscript received September 29, 2010; accepted in revised form October 10, 2011; published online February 24, 2012; issued February 29, 2012.

Shixue Hu \& Huilin Luo, Yunnan Institute of Geological Sciences, No. 87, Dongfeng Lane, East Dongfeng Road, 650051 Kunming, Yunnan Province, China; hushixue@hotmail.com・Maoyan Zhu, Fangchen Zhao, State Key Laboratory of Palaeobiology and Stratigraphy, Nanjing Institute of Geology and Palaeontology, Chinese Academy of Sciences, 210008 Nanjing, China $\bullet$ Michael Steiner, Angela Forchielli \& Helmut Keupp, Institut für Geologische Wissenschaften, Freie Universität Berlin, Malteserstraße 74-100, D-12249 Berlin, Germany • Qi Liu, Faculty of Earth Science, China University of Geosciences, 430074 Wuhan, China

Priapulids were important components of early Cambrian infaunal communities. Well-preserved fossil priapulids are mainly recovered from exceptional fossil Lagerstätten (Schram 1973; Conway Morris 1977; Conway Morris \& Robison 1986; Hou et al. 2004; Huang 2005, 2006; Conway Morris \& Peel 2010). The early Cambrian Chengjiang fossil Lagerstätte yields the most diverse record of fossil priapulids (Han et al. 2003, 2004; Hou et al. 2004; Huang et al. 2004a, b; Huang 2005). Although the controversy about their affinities continues, most authors have accepted the hypothesis that palaeoscolecidans represent a special group of priapulids (Conway Morris 1997, Wills 1998, Huang et al. 2004b, Hu 2005, Huang 2006, Harvey et al. 2010). Fossil records of palaeoscolecidans range from Cambrian Series 2 to late Silurian (Whittard 1953, Glaessner 1979, Mikulic et al. 1985, Conway Morris \& Robison 1986, Kraft \& Mergl 1989, Hintz et al. 1990, Müller \& Hinz-Schallreuter 1993, Zhang \& Pratt 1996, Ivantsov \& Wrona 2004, Lehnert \& Kraft 2006). Complete specimens of priapulids with preserved soft parts were, however, only found in Burgess Shale-type fossil Lagerstätten. Traditionally, palaeoscolecidans have been described from disarti- culated skeletal remains or phosphatized cuticle fragments, where major emphasize is laid on the structures and architecture of sclerites (Wrona 1982, 1987, 2004; Hintz et al. 1990; Müller \& Hintz-Schallreuter 1993; Zhang \& Pratt 1996; Lehnert \& Kraft 2006; Topper et al. 2010) or, alternatively, from rather complete compressions of individuals in claystone matrix, where the sclerites are often dissolved (e.g. Conway Morris 1977, Conway Morris \& Peel 2010) and thus the taxonomy is based on the overall bauplan and the dimensions of organisms. Taxonomical treatment of both disarticulated skeletal remains or soft-tissue preserved material with missing information on sclerites may be problematic for palaeocolecidans and other priapulid clades. The part-based nature of taxonomy (sensu Bengtson 1985) has indeed been proven for disarticulated sclerites of Hadimopanella preserved in more complete cuticular fragments (Topper et al. 2010). The aim of our study is to combine the information from soft-tissue preservation in mudstone-hosted fossil Lagerstätten, such as Cambrian Burgess Shale-type deposits or the Ordovician Klabava Fm. and Dobrotivá Fm. deposits (Kraft \& Mergl 1989), with information on the sclerite architecture, size ranges, 


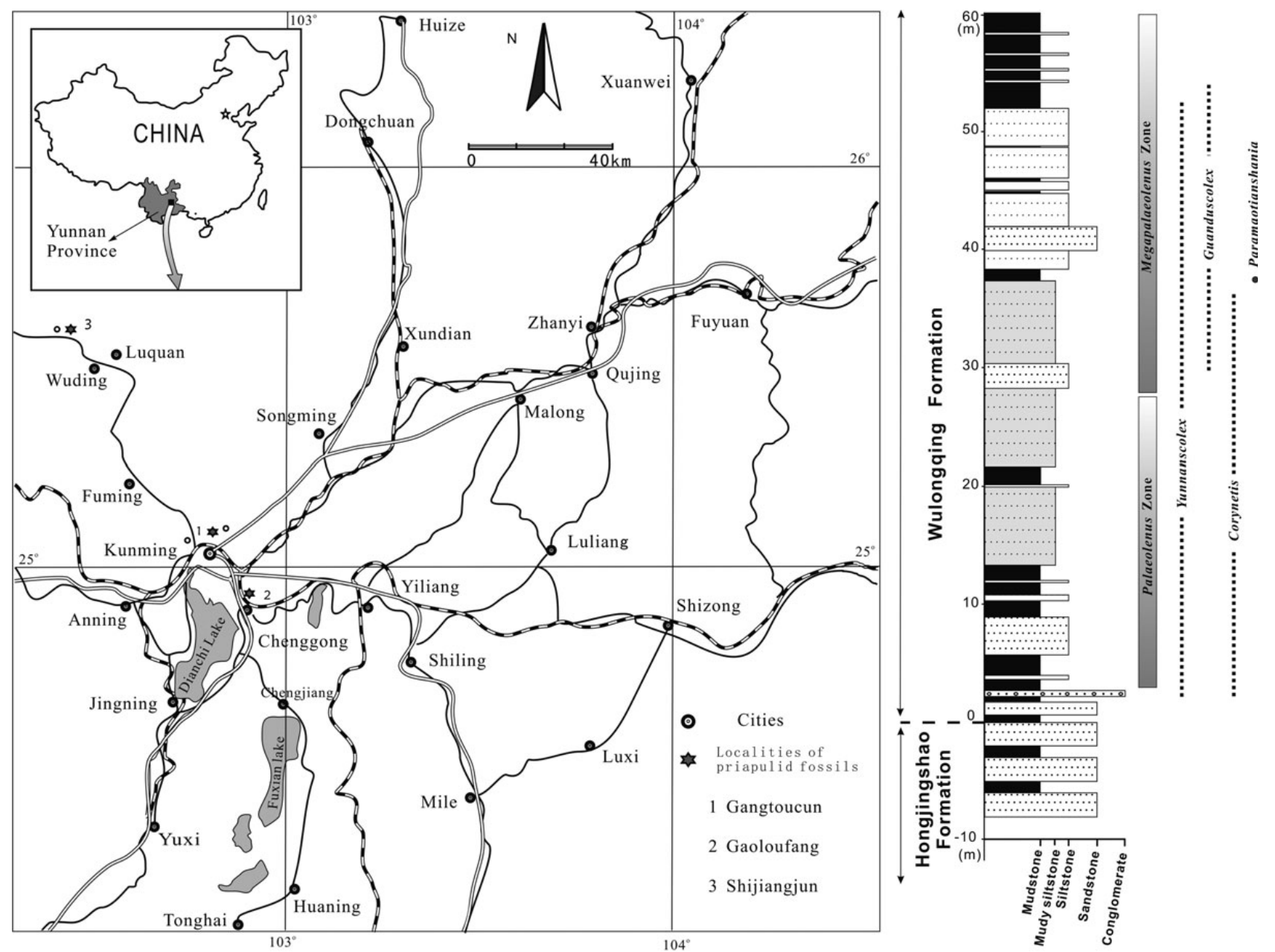

Figure 1. Locality map of the fossil priapulids from the Guanshan Lagerstätte in east Yunnan (left) and the lithology log and stratigraphic distribution of trilobite zones and priapulid fossils of the Wulongqing Formation at the Gaoloufang village, near Kunming (right).

and sclerite structures by applying backscatter-electron (BSE) imaging of cuticle and scleritom imprints from mudstones of the Guanshan fossil Lagerstätte.

\section{Geological setting and fossil preservation}

The Guanshan fossil Lagerstätte (Cambrian Series 2, Stage 4) represents an important Burgess Shale-type fossil Lagerstätte on the Yangtze Platform, South China. The intervals containing exceptionally preserved fossils belong to the Wulongqing Formation, normally composed of mudstones interbedded with siltstones. Two biostratigraphic zones, the lower Palaeolenus Zone and the upper Megapalaeolenus Zone of the Wulongqing Formation are commonly accepted (Zhang et al. 1980, Luo et al. 1994). The Guanshan fossil Lagerstätte is slightly younger than the famous Chengjiang fossil Lagerstätte; thus it is crucial for understanding the marine diversity between the renowned Chengjiang, Kaili, and Burgess Shale deposits. So far, approximately 15 fossil groups have been recovered, including trilobite and non-trilobite arthropods, brachiopods, sponges, eocrinoid echinoderms, hyolithids, vetulicoliids, priapulids, chancellorids, anomalocaridids, and algae (Luo et al. 1999, 2005, 2006, 2007; Liu et al. 2006; Hu et al. 2007, 2008, 2010a, b). Extensive excavations carried out in recent years by the working team from the Yunnan Institute of Geological Sciences in outcrops scattered throughout large areas of East Yunnan reveal a high diversity of priapulids in this fossil Lagerstätte. The most important fossil localities of priapulid fossils include Gangtoucun and Gaoloufang of Kunming City, and Shijiangjun of Wuding County, among which Gaoloufang is extensively investigated and shows great potential of priapulid fossil preservation (Fig. 1). Until now, 4 palaeoscolecidans and one corynetiid have been identified, of which the palaeoscolecidan Guanduscolex minor has been formally published ( $\mathrm{Hu}$ et al. 2008). Stratigraphically, the Guanshan palaeoscolecidans are equivalent to palaeoscolecidans from the Sinsk Formation of Siberian Platform 
(Ivantsov \& Wrona 2004, Ivantsov \& Zhuravlev 2005) and Kangaroo Island, South Australia (Glaessner 1979).

All priapulid fossils are found in yellowish to greenish mudstone of the Wulongqing Formation. The mudstone layers normally show sharp and erosive bases and are fining upwards, ranging from $0.5 \mathrm{~cm}$ to $2 \mathrm{~cm}$ in thickness. Multiple graded silt-mud couplets are commonly observed. Complete and articulated palaeoscolecidans are mostly preserved in the layers with low-grade or no bioturbation. It is interesting to note that most palaeoscolecidans are flattened and compressed, whereas most corynetiids are 3-D preserved, across several millimetres to maximum $10 \mathrm{~mm}$ within the host mudstone. Among the palaeoscolecidans, those from the upper part of the Wulongqing Formation in Gaoloufang, Kunming, including Guanduscolex and Paramaotianshania, show relatively better preservation of soft parts (i.e., introverts, gut trace, etc.). The living environment of the Guanshan Biota was reconstructed as a storm-dominated offshore transition, between fair-weather wave base and storm wave base, and within the photic zone, $40-50 \mathrm{~m}$ in depth (Hu et al. 2010b). Together with other associated fossil groups, the preservation of the Guanshan priapulids likely resulted from storm-induced rapid burial.

The priapulid fossils normally appear as reddish-brown or grayish-white staining, which contrast well with the surrounding yellowish green matrix. Elemental mapping and Energy Dispersive X-ray Spectrometric Microanalysis reveals that the cuticles of most palaeoscolecidans are iron oxides pseudomorphies after pyrite.

\section{Material and methods}

Specimens of fossil priapulids available in this study were obtained by splitting mudstone slabs in the field. Different parts of a priapulid individual may be preserved on either side of the slab. Further preparation was carried out in the laboratory with sharp blades under a binocular microscope. Small pieces of palaeoscolecidans with cuticular fragments obtained in the field or during preparation are utilized for SEM analysis due to size requirements and the necessity of gold coating.

Whole specimens or small pieces of palaeoscolecidan trunk fragments were analysed in the scanning electron microscope (SEM) laboratories of Freie Universität Berlin (using a ZEISS-SUPRA 40VP) and China University of Geosciences. Large or complete samples were not coated prior to analysis, whereas small pieces were coated with gold. All material is reposited in the Yunnan Institute of Geological Sciences, Kunming, Yunnan Province, China. Enlargement of details in mm scale are photographed with a Nikon camera mounted on a photomicrographic system in the Fossil Office of the Chengjiang County.
The nomenclature applied in this study is a combination of both modern (Land 1970) and fossil priapulids (Conway Morris 1977). Specific terms for palaeoscolecidans are after Conway Morris (1997), Conway Morris \& Robison (1986), Kraft \& Mergl (1989), Zhang \& Pratt (1996), Müller \& Hinz-Schallreuter (1993), and Ivantsov \& Wrona (2004) with slight modification. Three levels of cuticular ornaments are applied: protuberances, plates, and platelets based on their size. No microplates as mentioned by Han et al. (2007) have been observed on any of the three new palaeoscolecidans described herein.

\section{Systematic palaeontology}

Phylum Priapulida Delage \& Herouard, 1897

Class Palaeoscolecida Conway Morris \& Robison, 1986

Order and family uncertain

\section{Yunnanoscolex gen. nov.}

Type species. - Yunnanoscolex magnus sp. nov.

Derivation of name. - Referring to its wide occurrence in the area of East Yunnan and derived from the Greek word scolex [skölēk] - worm.

Diagnosis. - Body large, long, slender, and cylindrical. Trunk densely annulated. Each annulation is ornamented by quincunxially arranged plates. Plates large and round, equal in size, approximately $40-45 \mu \mathrm{m}$ in diameter, with 2-6 nodes (normally 5) on the upper surface of the plates. Neighbouring plates on succeeding rows space alternatively. Protuberances are irregularly present on ventral side of posterior annulations, approximately $200-300 \mu \mathrm{m}$ in diameter. A pair of stout hooks is present at the end of the posterior trunk.

Discussion. - The introvert part is unknown. Compared to other palaeoscolecidans, this animal is characteristic of its unusually large body size and relatively big plates. The observed maximum length is $100 \mathrm{~mm}$ and the maximum width is $8 \mathrm{~mm}$. The plates of the current genus are similar to that of Wronascolex spinosus from the lower Cambrian of eastern Siberia (Ivantsov \& Wrona 2004, Ivantsov \& Zhuravlev 2005), but the new taxa differs in quincunxially arranged plates and centre nodes, and the shape of ventral protuberances. Although the plates of Yunnanoscolex with 2-6 nodes are similar to some type of Hadimopanella oezgueli with 2-15 nodes (Wrona \& Hamdi 2001) and those of Hadimopanella apicata with 2-3 nodes (Topper et al. 2010), Hadimopanella is a form taxa based on isolated sclerites. Direct comparisons between isolated sclerites and complete specimens are not straightforward because it 
has been proved that different type-species of isolated sclerites may occur in one scleritome (Müller \& Hinz-Schallreuter 1993, Ivantsov \& Wrona 2004). The plates of middle Cambrian Corallioscolex (Müller \& Hinz-Schallreuter 1993) also similar to that of Yunnanoscolex in having several nodes, but the two taxa can be distinguished from each other by the presence of platelets and reticulate or cellular structure surrounding the plates and platelets in Corallioscole.

\section{Yunnanoscolex magnus sp. nov.} Figure 2A-K

Derivation of name. - From the Latin word magnus - large, referring to the large size of this animal.

Holotype. - GKG-125.

Material. - A total of 50 specimens, most of which are fragmental and only few are nearly complete.

Diagnosis. - Same as for genus.

Description. - The body is long and large, with $8 \mathrm{~mm}$ maximum height and length exceeding $100 \mathrm{~mm}$ (Fig. 2A-C). The trunk is densely annulated. Each annulation is ornamented by plates (Fig. 2D). The plates are arranged quincunxially. In most specimens the boundary between two succeeding annulations is not discernible. Two to six prominent nodes are present on the upper surface of the plates (Fig. 2E-K). In most cases the number of nodes is 5 (Fig. 2F, G). Neighbouring plates on succeeding rows space alternatively. Large protuberances are irregularly present on ventral side of posterior segments, approximately 200-300 $\mu \mathrm{m}$ in diameter (Fig. 2J). No introvert was preserved.

Traces of intestine are observed occasionally, running longitudinally as a dark line or stripe. On a few specimens a pair of strong hooks can be observed clearly on the end of the trunk. Each hook is $0.5 \mathrm{~mm}$ in length and $0.2 \mathrm{~mm}$ in diameter at the base, curved and terminated to a sharp point.

Occurrence. - Palaeolenus Zone and Megapalaeolenus Zone, Wulongqing Formation, Canglangpuan Stage, Cambrian Series 2, Wuding County and Kunming City, Yunnan Province, China.
Order and family uncertain

\section{Wudingscolex gen. nov.}

Type species. - Wudingscolex sapushanensis sp. nov.

Derivation of name. - Referring to its occurrence in the Wuding County and derived from the Greek word scolex [skōlék] - worm.

Diagnosis. - Body large, long, slender, and cylindrical. Trunk densely annulated. Each annulation is ornamented by two rows of large plates and numerous platelets. Plates round, arranged in transverse rows; with one or two central nodes and three circles of nodes outside. The inner circle has 6-9 nodes; the middle circle has 10-13 nodes; the outer circle has 20 nodes. The size of the plates mostly ranges from 75 to $95 \mu \mathrm{m}$. Platelets distributed between rows of plates and within two plates, arranged in a quincunxial pattern, with 8-10 marginal nodes and one or two central nodes. The size of the platelets mostly ranges between 35 and $50 \mu \mathrm{m}$. Large projections or protuberances are regularly present on the ventral side of segments at the posterior part of the trunk, approximately $100 \mu \mathrm{m}$ in diameter. Each segment has at least 6 protuberances.

Discussion. - This genus resembles Yunnanoscolex in its larger body size, the plates, and presence of protuberances on the one side. However, the former differs in having larger plates with three circles of nodes, and the presence of quincunxially arranged platelets. The introvert parts of both genera are currently unknown.

Occurrence. - Cambrian Series 2, Wulongqing Formation.

\section{Wudingscolex sapushanensis sp. nov.}

Figures $3 \mathrm{~A}-\mathrm{G}$

Derivation of name. - After the hill Sapushan, where the holotype was recovered.

Holotype. - Wsh-14-34.

Paratypes. - Wsh-14-32.

Figure 2. Yunnanoscolex magnus sp. nov. $\bullet$ A - holotype, GKG-125, from Gaoloufang village, Kunming City. $\bullet$ B - paratype, GKG-126, collected from Gaoloufang village, Kunming City. $\bullet$ C - GWS-01, collected from Sapushan, Wuding City. $\bullet$ D - SEM micrographs showing the details of the arrangement of cuticular structures, GKG-127, Gaoloufang, Kunming City. • E-I, K - SEM micrographs of GKG-196, showing plates with different numbers of nodes (from 4 to 6), Gaoloufang, Kunming. $・$ J - Wsh-4-13, showing the protuberance. Sapushan, Wuding City. Abbreviations: Ho - hook 

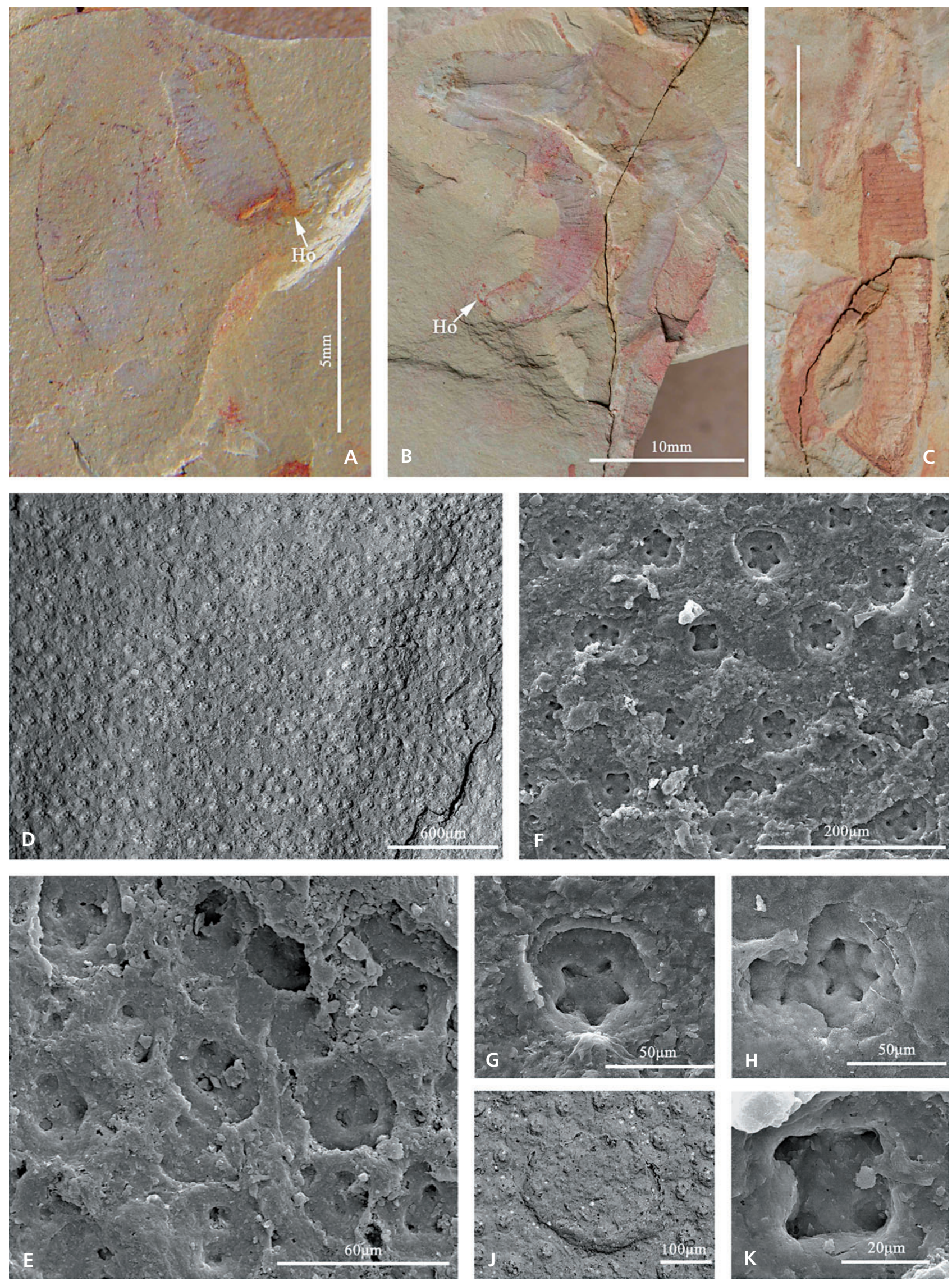
Material. - Two specimens available for current study.

Diagnosis. - Same as for genus.

Description. - The body is large and long, with a maximum height of $8 \mathrm{~mm}$ and a length exceeding $80 \mathrm{~mm}$ (Fig. 3A, B). Each annulation is ornamented by two rows of plates and numerous platelets (Fig. 3C-E). The plates are round, arranged in transverse rows, with one or two nodes in the centre and three circles of nodes outside. The inner circle has 6-9 nodes; the medium circle with 10-13 nodes; the outer circle with ca 20 nodes (Fig. 3G). The distance between two plates varies, averaging approximately $100 \mu \mathrm{m}$. The platelets are round and medium-sized ( $c$ a 35-50 $\mu \mathrm{m}$ ), distributed uniformly between rows of platelets and within two plates of the same row. Each platelet has a circle of 8-10 marginal nodes and one or two central nodes. Protuberances are large, about 100-200 $\mu \mathrm{m}$ in diameter (Fig. 3F), and regularly present on the ventral side of segments at the posterior part of the trunk. At least 6 protuberances are seen on one segment.

No introverts have been observed from all collected specimens, so the details of the introvert are unknown.

Occurrence. - Palaeolenus Zone and Megapalaeolenus Zone, Wulongqing Formation, Canglangpuan Stage, Cambrian Series 2, Wuding County, Yunnan, China.

Family Maotianshaniidae Hou et al., 1999

Genus Paramaotianshania gen. nov.

Type species. - Paramaotianshania zijunia sp. nov.

Derivation of name. - From the Latin para-, referring to its similarity with the Maotianshania from the slightly older Chengjiang fauna.

Diagnosis. - Body small and cylindrical, divided into an anterior introvert and a posterior trunk. Introvert relatively narrow, armed with scalids. Trunk finely annulated, with distinct ridges. Annulations are ornamented by small plates. Hair-like protuberances irregularly present on surface of trunk. Width of the hair-like protrusions is in the range of some tens of $\mu \mathrm{m}$, length ranging from ca 100 to $350 \mu \mathrm{m}$. Each annulation bears uniformly arranged plates. Plates equal in size, ranging from 13 to $25 \mu \mathrm{m}$ (mostly 15-20 $\mu \mathrm{m})$ in diameter. Four nodes are present at the convex upper surface of each plate.

Discussion. - The new genus closely resembles Maotianshania in uniformly arranged plates with 4 nodes on each plate (Hu 2005). However, Paramaotianshania differs in larger body size, the presence of hair-like protuberance, and the distinct ridge between annulations. The maximal width of mature individuals is up to $6 \mathrm{~mm}, 6$ times that of Maotianshania.

Occurrence. - Cambrian Series 2, Wulongqing Formation.

\section{Paramaotianshania zijunia sp. nov.}

Figure 4A-K

Derivation of name. - The species is named after the Zijun hill, where the specimens were collected.

Holotype. - Specimen GKG-123a, figured here as Fig. 4A, C.

Material. - 15 specimens, of which 3 with introverts preserved.

Diagnosis. - Same as for genus.

Description. - The size of the body varies from juveniles to mature individuals. The minimal width is $1 \mathrm{~mm}$ in juveniles (Fig. 4A, B) and the maximum width is $6 \mathrm{~mm}$ in mature individuals (Fig. 4D). The body consists of two parts: an anterior introvert and a posterior trunk.

The introvert (Fig. 4A-C) has the same width as the trunk, bearing stout scalids (Fig. 4E). The details of the scalids are unclear due to poor preservation. The pharynx can be seen on few individuals, normally inverted, bearing spine-like pharyngeal teeth on the surface.

The trunk has a uniform width. The most proximal part (ca $5 \mathrm{~mm}$ in length) is devoid of annulations and ornaments (Fig. 4C, E). Most of the trunk is finely annulated. The number of annulations per mm varies according to growth age, ranging from 8 per millimeter in juveniles to 2 in mature individuals. The total number of annulations on the entire body is difficult to count. Uniformly arranged plates are present on the surface of annulations (Fig. 4G, H, K). The size of a single plate is mostly approximately 15-20 $\mu \mathrm{m}$ in diameter (Fig. 4I, J). Each plate contains 4 nodes. No platelets are observed between the plates.

Figure 3. Wudingscolex sapushanensis sp. nov. • A - holotype, Wsh-14-34. • B - paratype, Wsh-14-32. • C-F - SEM micrographs of cuticle structures of the holotype. $\mathrm{C}$ and $\mathrm{D}$ show the overall arrangement of plates and platelets; E shows the detail of two ventral protuberances; F shows the details of a plate. 
Shixue Hu et al. - A new priapulid assemblage from the early Cambrian Guanshan fossil Lagerstätte of SW China
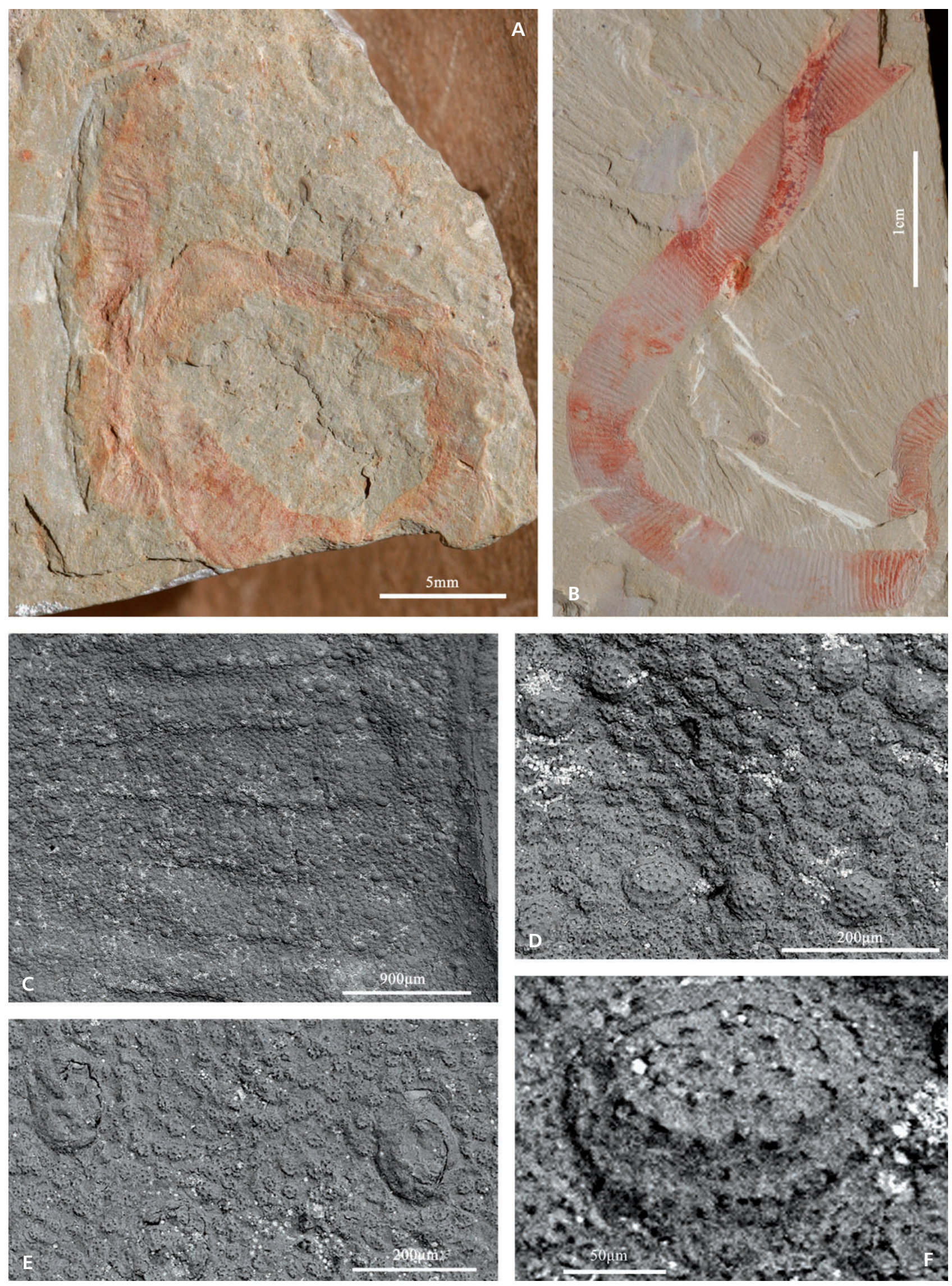
Hair-like protuberances (Fig. 4F) are irregularly present on the trunk surface.

The gut is preserved as a dark strand, running longitudinally along the body, beginning from the tip of the pharynx and terminating at the position of the anus.

Occurrence. - Megapalaeolenus Zone, Wulongqing Formation, Canglangpuan Stage, Cambrian Series 2, Gaoloufang village, Kunming City, Yunnan, China.

\section{Class uncertain \\ Corynetidae Huang, Vannier \& Chen, 2004}

\section{Corynetis Luo \& Hu, 1999}

Type species. - Corynetis brevis Luo \& Hu, 1999.

Emended diagnosis. - Medium-sized priapulid worm. Introvert smooth and contrasted with a circle of strong and long spines at the anterior end. No neck area present. Trunk densely annulated. Trunk diameter uniform or increasing towards the end. A ring of strong spines present on each annulation. The size of the spines decreases from posterior to anterior annulations. Collar narrow, tapering forward. Pharynx elongate. Pharyngeal teeth dense and spine-like, arranged in oblique line.

Occurrence. - Cambrian Series 2, Wulongqing and Yuanshan formations.

\section{Corynetis fortis sp. nov.}

Figures 5A-L, 6

Derivation of name. - The species name is derived from the Latin word fortis - strong, indicating the larger size and strong spines on the surface of annulations.

Holotype. - GKG-128, a complete specimen.

Paratypes. - GKG-131, a complete individual.

Material. - More than 100 specimens, of which 10 are complete, with well-preserved introverts and pharynx.

Diagnosis. - The body is large, with a width ranging from 3 to $8 \mathrm{~mm}$ (average $6 \mathrm{~mm}$ ); The exact length of the body is difficult to measure due to strong contraction of most individuals. The observed maximal length is $65 \mathrm{~mm}$.

Most parts of the introvert are smooth, slightly contracting forward. A circle of long and strong spines is present at the anterior end of the introvert. The maximal length of the spines observed is $6 \mathrm{~mm}$. A short and wide collar is present between the introvert and the pharynx, slightly tapering forward. The pharynx is relatively long, normally inverted (Fig. 5A, B, G, I, J), armed with dense pharyngeal teeth. The pharyngeal teeth are spine-like, arranged in oblique line on the surface (Fig. 5J).

The trunk is strongly annulated, with an average width of $6 \mathrm{~mm}$ in mature individuals. The ridges between annulations are distinct at the posterior part, becoming weak forward and nearly indiscernible at the anterior part close to the introvert. The number of annulations is 4 per millimeter and a total of 160 annulations are estimated. Each annulation is covered by a ring of spines (Fig. 5D, K, L), about 30 in number. The spines on distal annulations are strong, pointed backward, with a base of $0.1 \mathrm{~mm}$ and a length of $0.5 \mathrm{~mm}$ in mature individuals (Fig. 5K). From the posterior part to the anterior part of the trunk the size of the spines decreases and the pointed end is slightly directed forward. The intestine is dark, mostly 3-D preserved, straight (Fig. 5B, F) or looped (Fig. 5E), normally filled with mud sediment. No caudal appendages have been observed.

Discussion. - The current form closely resembles the type species $C$. brevis in general morphology, notably the spiculose pharynx, the presence of a circle of long spines at the anterior end of introvert, and a ring of spines on each annulation. However, the new species differs in its larger size, the nearly uniform width of the trunk, the looped or distorted intestine. It should be noted that the backward expanded trunk is a species characteristic rather than a generic one, and should not be considered as a generic diagnosis (Huang et al. 2004a).

Occurrence. - Palaeolenus Zone and Megapalaeolenus Zone, Wulongqing Formation, Canglangpuan Stage, Cambrian Series 2, Gaoloufang and Gangtoucun village, Kunming City, Yunnan, China.

\section{Discussion and conclusions}

Although the presence of spines or papillae on some early Cambrian palaeoscolecidans was interpreted as indicative

Figure 4. Paramaotianshania zijunia sp. nov. $\bullet$ A, C - holotype, GKG-123a, C is the enlargement of the introvert and anterior part of the trunk of A. - B, E-GKG-123b, E is the enlargement of the introvert of the individual in the upper part. $\bullet$ D - GKG-123c. $\bullet$ F - GKG-124, showing the hair-like protuberances (black arrows). $\bullet \mathrm{G}-\mathrm{K}-\mathrm{SEM}$ micrographs of cuticle structures. I is the enlargement of a single plate in G (black arrow); J is the enlargement of the frame in H. Abbreviations: In - intestine; Iv - introvert; Pr - protuberance; Sc - scalid; P - pharynx. 
Shixue Hu et al. • A new priapulid assemblage from the early Cambrian Guanshan fossil Lagerstätte of SW China
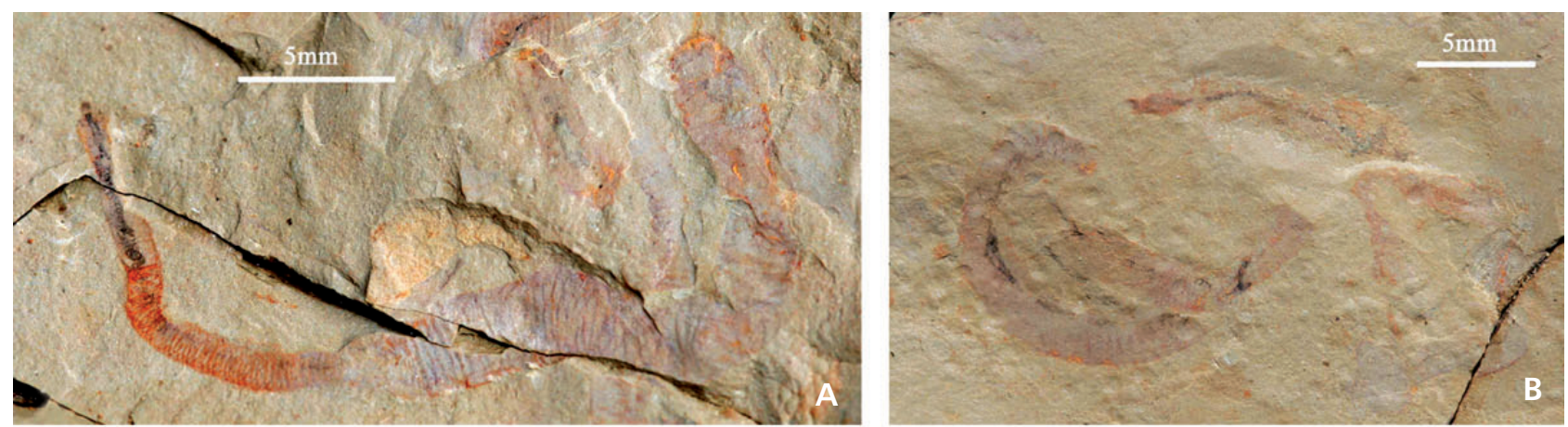
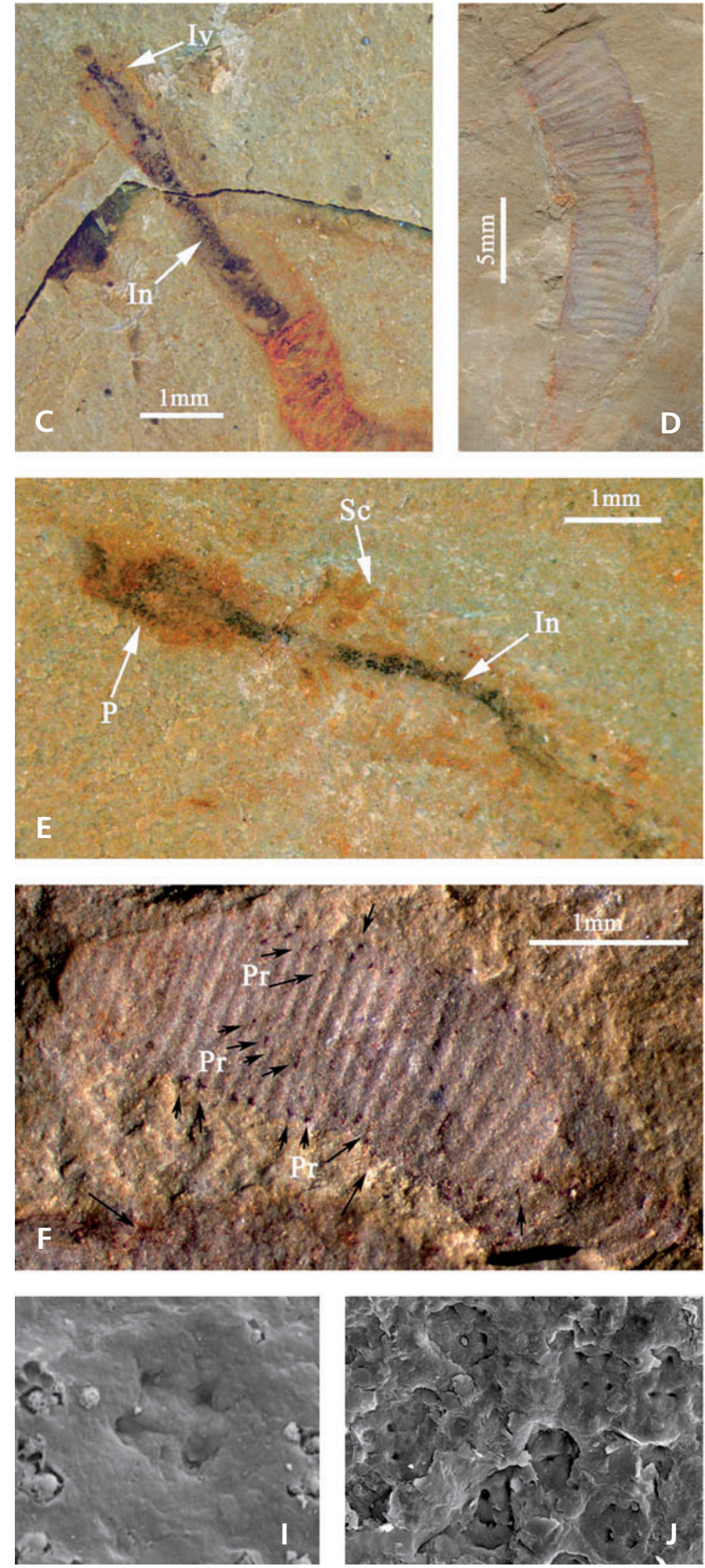
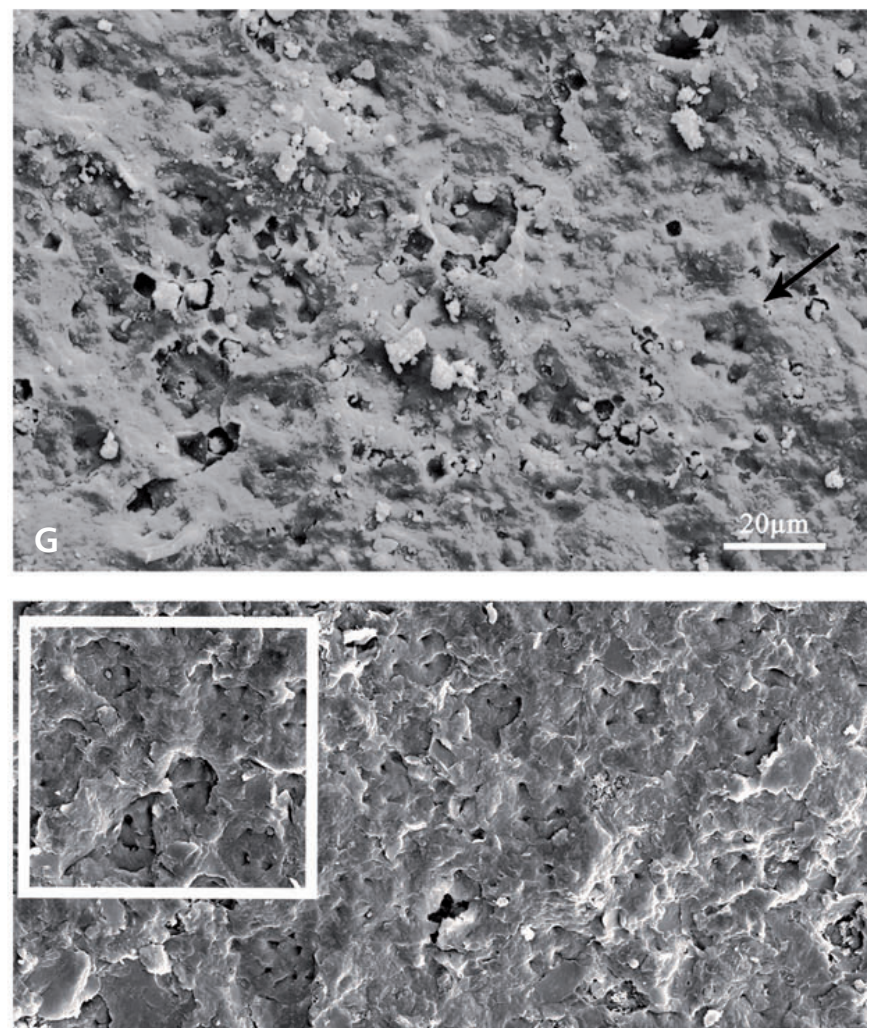

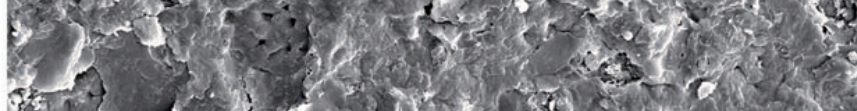

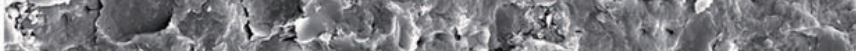

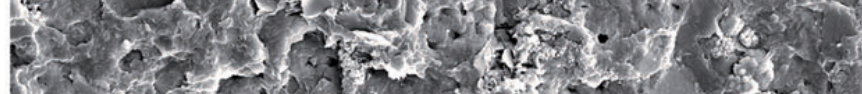

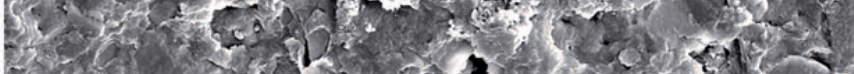

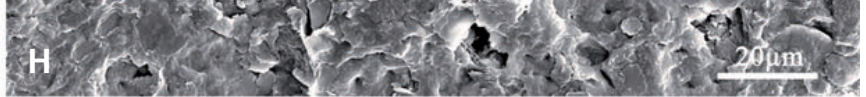

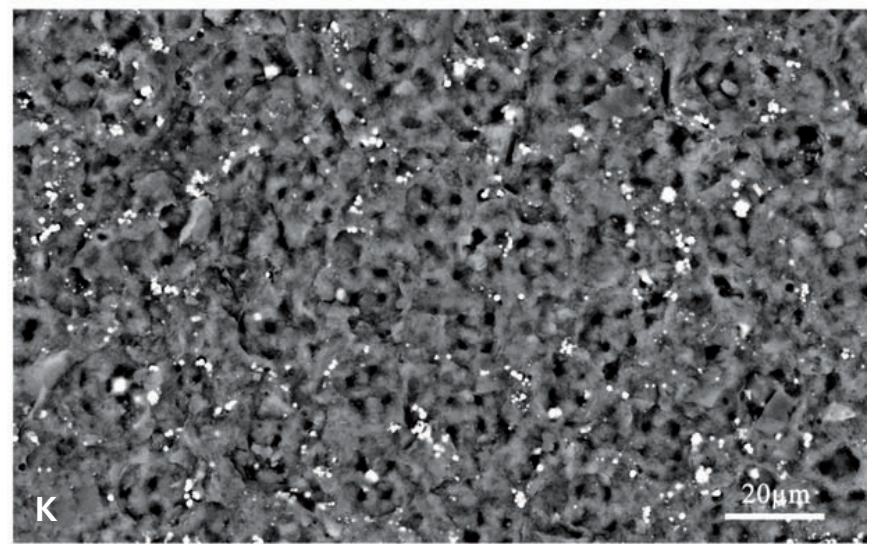


of possible epifaunal lifestyle (Müller \& Hinz-Schallreuter 1993, Zhang \& Pratt 1996, Ivantsov \& Wrona 2004, Mass et al. 2007), convincing evidence of burrowing has been reported from some Chengjiang palaeoscolecidans with dorsal-ventral differentiation (Hu 2005, Zhang et al. 2006, Han et al. 2007). Some individuals of Cricocosmia and Mafangscolex are preserved within burrow traces ( $\mathrm{Hu}$ 2005, Zhang et al. 2006). Han et al. (2007) proposed another alterative interpretation: that the ventral spines of $\mathrm{Cri}$ cocosmia and trunk papillae of Mafangscolex may have functioned for respiration and helped in fertilization, to increase friction in burrowing, or for mucus secretion from glands.

Dzik (2005, 2007) has compared structures of Cambrian priapulids known from the Burgess Shale and the Chengjiang mudstones with mostly Cambrian sequential, horizontal burrows and bilobate traces and concluded that much of the tubular serial burrows, including treptichnids, were produced by priapulids. During experimental ichnological studies with modern priapulids Vannier et al. (2010) were able to show that typical serial burrows of treptichnids were most probably produced by priapulids during shallow probing for infaunal or epifaunal prey. The strata yielding the new taxa of palaeoscolecidan and corynetiid priapulid described herein also contain a great variety of trace fossils, among which are also common treptichnid burrows (see Weber et al. 2012, this volume). The dimensions of the treptichnid burrows fit well with the dimensions of palaeoscolecidans described herein. Thus, a trace-producing of the treptichnids galleries by palaoscolecidans might be supported herein.

Possible ventral protuberances are also observed from some Guanshan palaeoscolecidans, such as Yunnanoscolex and Wudingscolex. An infaunal lifestyle for the Guanshan palaeoscolecidans is supported by the current study. Rather than indicating an epibenthic lifestyle, these structures presumably provided points d'appui to allow the animal to gain purchase on sediment and to increase friction against the matrix while burrowing (Kraft \& Mergl 1989, Conway Morris 1997). However, the early Cambrian palaeoscolecidans were only active in the upper tier of the sediments because only shallow traces have been observed associated with these worms. By contrast, the Guanshan corynetiids are likely deep burrowers, exploring a deeper tier of the substrate. Some individuals of Corynetis fortis sp. nov. are preserved together with their vertical burrows. In some cases the vertical extension of the trace can reach $10 \mathrm{~mm}$. An original burrowing depth of $50 \mathrm{~mm}$ can thus be inferred if the 1:5 ratio of compaction for mudstone is accepted. Corynetiid priapulids might have contributed to more of the deep burrows in the early Cambrian sediments than previously thought.

Most Cambrian priapulids are thought to be predators (Conway Morris 1977; Bruton 2001; Huang et al. 2004b; Hu 2005; Huang 2005, 2006). The Guanshan priapulids, including both the palaeoscolecidans and corynetiids, are also interpreted as predators because of their spiny pharynxes, which are comparable to those of their modern analogues. The circle of long oral spines of Corynetis and Anningvemis was suggested (Huang et al. 2004a) as having functioned for attracting prey. This is probably the case for C. fortis too.

Although some of the Cambrian priapulids were interpreted as deposit-feeders because of their mud-filled gut (Conway Morris 1977, Briggs et al. 1994, Hou et al. 2004), evidence provided by Butterfield (2002) indicated that the mud-filling of the gut of the Burgess Shale arthropod Leanchoilia was the result of the weathering of phosphate premineralisation of midgut glands. So the mud-filled gut of the Corynetis from the Guanshan fossil Lagerstätte also might have been secondary, and their feeding strategy is considered to be that of predators rather than deposit feeders.

The discovery of the new priapulid assemblage from the early Cambrian Guanshan fossil Lagerstätte greatly increased our knowledge about the diversity of Cambrian priapulids and sheds new light on anatomy, functional morphology, and lifestyles of this animal group. The occurrence of abundant and diverse priapulids from both of the Chengjiang and Guanshan fossil Lagerstätten from East Yunnan indicates a possible radiation centre of this animal group on the soft-substratum shelf of the Yangtze Platform during the early Cambrian period.

\section{Acknowledgement}

This work is supported by National Natural Science Foundation of China (Grant No. 40772020, 41002002), Chinese Academy of Sciences (KZCX2-EW-115), and Deutsche Forschungsgesellschaft (KE 322/34-1). The authors are grateful to Li Guoxiang,

Figure 5. Corynetis fortis sp. nov. A A, I- holotype, GKG-128, a complete individual with inverted introvert. I is enlargement of the introvert, showing the circle of long spines (Is) at the anterior end of the introvert and the inverted pharynx (P). $\bullet$ B - GKG-129, a juvenile. $\bullet$ C - GKG-130, an incomplete individual with everted introvert, showing the long spines of introvert (Is) and rows of spines on anterior part of the trunk. $\bullet$, K, L - GKG-131, a complete individual with inverted introvert. $\mathrm{K}$ and $\mathrm{L}$ are enlargements of the posterior parts of the trunk, showing dense spines on the surface of annulations. - E-GKG-132, showing the looped intestine. $\bullet \mathrm{F}, \mathrm{H}-\mathrm{GKG}-133$. H is the enlargement of the introvert, showing the circle of long spines at the anterior part of the introvert. $\bullet \mathrm{G}, \mathrm{J}-\mathrm{GKG}-133$, J is the enlargement of the inverted introvert, showing the arrangement and details of pharyngeal teeth. Abbreviations: In - intestine; Is - introvert spine; Iv - introvert; Sc - scalid; P - pharynx; Pt - pharyngeal teeth; Sp - spine. 
Shixue Hu et al. - A new priapulid assemblage from the early Cambrian Guanshan fossil Lagerstätte of SW China
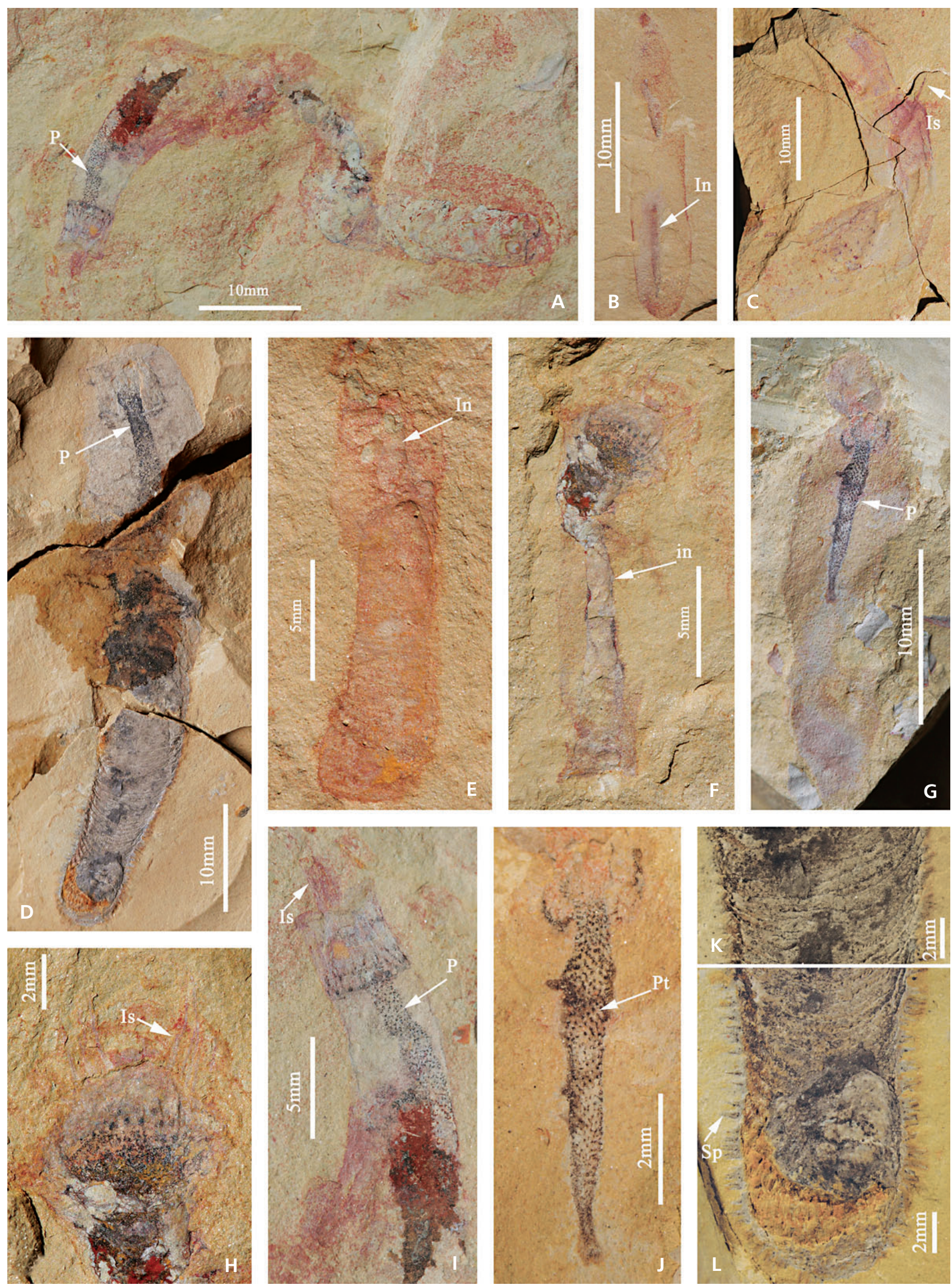


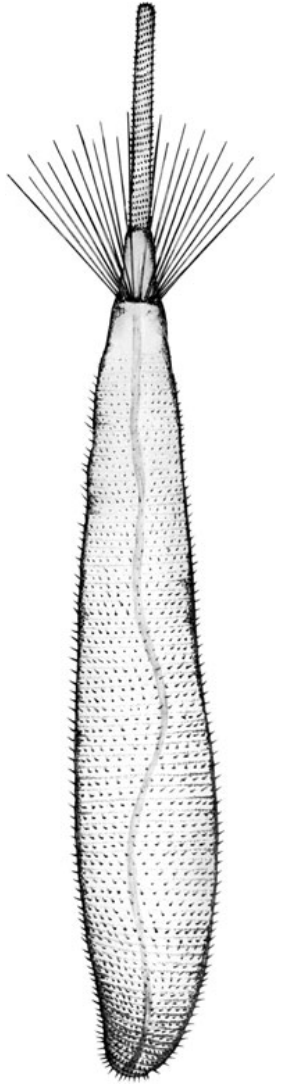

Figure 6. Reconstruction of Corynetis fortis sp. nov.

Huang Diying, Zhang Xingliang, Han Jian, and Zhang Zhifei, Zhao Yuanlong for constructive discussion and suggestions. Thanks are also given to Chen Ailin for use of the photomicrographic system. We also thank Chen Qingtao for field assistance and reconstruction, and Anne Beck for improving the English of this manuscript.

\section{References}

Bengtson, S. 1985. Taxonomy of disarticulated fossils. Journal of Paleontology 59, 1350-1358.

Briggs, D., Erwin, D. \& Collier, F. 1994. The fossils of the Burgess Shale. 238 pp. Smithsonian Institution Press, Washington.

BRUTON, D.L. 2001. A death assemblage of priapulid worms from the Middle Cambrian Burgess Shale. Lethaia 34, 163-167. DOI 10.1080/00241160152418456

ButTERFIELD, N.J. 2002. Leachoilia guts and the interpretation of three-dimensional structures in Burgess Shale-type fossils. Paleobiology 28, 155-171.

DOI 10.1666/0094-8373(2002)028<0155:LGATIO>2.0.CO;2

Conway Morris, S. 1977. Fossil priapulid worms. Special Papers in Palaeontology 20,1-95.

Conway Morris, S. 1997. The cuticular structure of the 495Myr-old type species of the fossil worm Palaeoscolex, P. pis- catorum (?Priapulida). Zoological Journal of the Linnean Society 119, 69-82.

DOI 10.1111/j.1096-3642.1997.tb00136.x

Conway Morris, S. \& Robison, R.A. 1986. Middle Cambrian priapulids and other soft-bodied fossils from Utah and Spain. University of Kansas Paleontological Contributions 117, $1-22$.

Conway Morris, S. \& Peel, J.S. 2010. New palaeoscolecidan worms from the Lower Cambrian: Sirius Passet, Latham Shale and Kinzers Shale. Acta Palaeontologica Polonica 55, 141-156. DOI 10.4202/app.2009.0058

DzIK, J. 2005. Behavioral and anatomical unity of the earliest burrowing animals and the cause of the "Cambrian explosion". Paleobiology 31, 503-521.

DOI 10.1666/0094-8373(2005)031[0503:BAAUOT]2.0.CO;2

DzIK, J. 2007. The Verdun Syndrome: simultaneous origin of protective armour and infaunal shelters at the Precambrian-Cambrian transition, 405-414. In VICKERS-RICH, P. \& KOMAROWER, P. (eds) The Rise and fall of the Ediacaran Biota. Geological Society of London, Special Publications 286.

Glaessner, M.F. 1979. Lower Cambrian Crustacea and worms from Kangaroo Island, South Australia. Alcheringa 3, 21-31. DOI 10.1080/03115517908565437

Han, J., Liu, J., Zhang, Z., Zhang, X. \& Shu, D. 2007. Trunk ornament on the palaeoscolecidan worms Cricocosmia and Tabelliscolex from the Early Cambrian Chengiang deposits of China. Acta Palaeontologica Polonica 52, 423-431.

Han, J., Zhang, X., Zhang, Z. \& Shu, D. 2003. A new platy-armored worm from the Early Cambrian Chengjiang Lagerstätte, South China. Acta Geologica Sinica 77 (English edition), 1-6.

Han, J., Zhang, Z. \& LiU, J. 2004. Taphonomy and ecology of the introverts from the Chengjiang fauna. Journal of Northwest University (Natural Science Edition) 34, 208-211. [in Chinese with English abstract]

Harvey, T., Dong, X. \& Donoghue, C. 2010. Are palaeoscolecids ancestral ecdysozoans? Evolution and Development 12, 177-200. DOI 10.1111/j.1525-142X.2010.00403.x

Hintz, I., Kraft, P., Mergl, M. \& Müller, K.J. 1990. The problematic Hadimopanella, Kaimenella, Milaculum and Utahphospha identified as sclerites of Palaeoscolecida. Lethaia 23, 217-221. DOI 10.1111/j.1502-3931.1990.tb01362.x

Hou, X.G., Aldridge, R.J., Bergström, J., Siveter, David J., Siveter, Derek J. \& Feng, X.H. 2004. The Cambrian fossils of Chengjiang, China: The flowering of early animal life. 248 pp. Blackwell Publishing, Malden \& Oxford. DOI 10.1002/9780470999950

Hu, S.X. 2005. Taphonomy and palaeoecology of the Early Cambrian Chengjiang Biota from Eastern Yunnan, China. Berliner Paläebiologische Abhandlungen 7, 1-197.

Hu, S.X., Li, Y., LuO, H.L., Fu, X.P., You, T., PANG, J.Y., Liu, Q. $\&$ STEINER, M. 2008. New record of palaeoscolecids from the Early Cambrian of Yunnan, China. Acta Geologica Sinica 82(2), 244-248. DOI 10.1111/j.1755-6724.2008.tb00574.x

Hu, S.X., Luo, H.L., Hou, S. \& ERDTMann, B.-D. 2007. Eocrinoid echinoderms from the Lower Cambrian Guanshan Fauna in 
Wuding, Yunnan, China. Chinese Science Bulletin 52, 717-719. DOI 10.1007/s11434-007-0083-6

Hu, S.X., Zhang, Z.F., Holmer, L.E. \& Skovsted, C.B. 2010a. Soft-part preservation in a linguliform brachiopod from the lower Cambrian Wulongqing Formation (Guanshan Fauna) of Yunnan, southern China. Acta Palaeontologica Polonica 55(3), 495-505. DOI 10.4202/app.2009.1106

Hu, S.X., Zhu, M.Y., Steiner, M., Luo, H.L., Zhao, F.C. \& Liu, Q. 2010b. Biodiversity and taphonomy of the early Cambrian Guanshan Biota, eastern Yunnan. Science China - Earth Sciences 53(12), 1765-1773. DOI 10.1007/s11430-010-4086-9

HuAng, D. 2005. Early Cambrian worms from SW China: Morphology, systematics, lifestyles and evolutionary significance. 247 pp. Ph.D. thesis, University of Lyon 1, Lyon.

HuAng, D. 2006. The early body plan, origin and evolutionary radiation of priapulida, 125-137. In RoNG, J., FANG, Z., ZHOU, Z., Zhan, R., Wang, X. \& YuAN, X. (eds) Originates, radiations and biodiversity changes - evidence from the Chinese Fossil Record. Science Press, Beijing. [in Chinese with English abstract]

Huang, D., Vannier, J. \& Chen, J. 2004a. Anatomy and lifestyles of Early Cambrian priapulid worms exemplified by Corynetis and Anningvermis from the Maotianshan Shale (SW China). Lethaia 37, 21-33. DOI 10.1080/00241160410005088

Huang, D., Vannier, J. \& Chen, J. 2004b. Recent Priapulidae and their Early Cambrian ancestors: comparisons and evolutionary significance. Geobios 37, 217-228.

DOI 10.1016/j.geobios.2003.04.004

Ivantsov, A.Y. \& WronA, R. 2004. Articulated palaeoscolecidan sclerites arrays from the Lower Cambrian of eastern Siberia. Acta Geologica Polonica 54, 1-22.

Ivantsov, A.Y. \& Zhuravlev, A.Y. 2005. Paleontological descriptions: Cephalorhynchs, 61-72. In Ponomarenko, A.G. (ed.) Unikalnye sinskiye mestonakhozhdeniya rannekembriyskikh organizmov. Trudy Paleontologicheskogo Instituta 284. [in Russian with English summary]

Kraft, P. \& Mergl, M. 1989. Worm-like fossils (Palaeoscolecida; ?Chaetognatha) from the Lower Ordovician of Bohemia. Sborník geologických věd, Paleontologie 30, 9-36.

LAND, V.J. 1970. Systematics, zoogeography and ecology of the Priapulia. Zoologische Verhandelingen, Leiden 112, $1-118$.

Lehnert, O. \& Kraft, P. 2006. Manitouscolex, a new palaeoscolecidan genus from the Lower Ordovician of Colorado. Journal of Paleontology 80, 386-391. DOI 10.1666/0022-3360(2006)080[0386:MANPGF]2.0.CO;2

Liu, Q., Luo, H.L., Chen, L.Z. \& Hu, S.X. 2006. Panlongia, a new trilobitomoph from Lower Cambrian, Kunming, Yunnan. Acta Palaeontologica Sinica 45, 384-391. [in Chinese with English summary]

Luo, H.L., Fu, X.P., Hu, S.X., Li, Y., Chen, L.Z., You, T. \& Liu, Q. 2005. New vetulicoliids from the Lower Cambrian Guanshan Fauna, Kunming. Acta Geologica Sinica (English edition) 79, 1-6. DOI 10.1111/j.1755-6724.2005.tb00860.x

Luo, H.L., Fu, X.P., Hu, S.X., Li, Y., Chen, L.Z., You, T. \& Liu, Q. 2006. New bivalved arthropods from the Early Cambrian
Guanshan fauna in the Kunming and Wuding area. Acta Palaeontologica Sinica 45, 460-469. [in Chinese with English abstract]

Luo, H.L., Fu, X.P., Hu, S.X., LI, Y., Hou, S.G., You, T., PAng, J.Y. \& Liu, Q. 2007. A new arthropod, Guangweicaris Luo, $\mathrm{Fu}$ et $\mathrm{Hu}$ gen. nov. from the Early Cambrian Guanshan Fauna, Kunming, China. Acta Geologica Sinica (English edition) $81,1-7$.

Luo, H.L., Hu, S.X., Chen, L.Z., Zhang, S.S. \& TaO, Y.H. 1999. Early Cambrian Chengjiang Fauna from Kunming region, China. 129 pp. Yunnan Science and Technology Press, Kunming. [in Chinese with English summary]

Luo, H.L., Jiang, Z. \& TAng, L. 1994. Stratotype section for Lower Cambrian stages in China. 183 pp. Yunnan Science and Technology Press, Kunming, China. [in Chinese with English abstract]

Maas, A., Huang, D.Y., Chen, J.Y., Waloszek, D. \& Braun, A. 2007. Maotianshan-Shale nemathelminths: Morphology, biology, and the phylogeny of Nemathelminthes. Palaeogeography, Palaeoclimatology, Palaeoecology 254, 288-306. DOI 10.1016/j.palaeo.2007.03.019

Mikulic, D.G., BRiggs, D.E.G. \& Kluessendorf, J. 1985. A new exceptionally preserved biota from the Lower Silurian of Wisconsin, U.S.A. Philosophical Transaction of the Royal Society of London, Series B, Biological sciences 311, 75-85. DOI 10.1098/rstb.1985.0140

Müller, K.J. \& Hinz-Schallreuter, I. 1993. Palaeoscolecidan worms from the Middle Cambrian of Australia. Paleontology $36,549-592$.

SCHRAM, F.R. 1973. Pseudocoelomates and a nemertine from the Illinois Pennsylvanian. Journal of Paleontology 47, 985-989.

Topper, T.P., Brock, G.A., Skovsted, C.A. \& Paterson, J.R. 2010. Palaeoscolecid scleritome fragments with Hadimopanella plates from the early Cambrian of South Australia. Geological Magazine 147, 86-97.

DOI 10.1017/S0016756809990082

Vannier, J., Calandra, I., Gaillard, C. \& ZylinsKa, A. 2010. Priapulid worms: Pioneer horizontal burrowers at the Precambrian-Cambrian boundary. Geology 38, 711-714.

DOI 10.1130/G30829.1

Weber, B., Hu, S.X. \& Steiner, M. 2012. A diverse ichnofauna from the Cambrian Stage 4 Wulongqing Formation near Kunming (Yunnan Province, South China). Bulletin of Geosciences 87(1), 71-92.

DOI 10.3140/bull.geosci.1239

WhitTARD, W.F. 1953. Palaeoscolex piscatorum gen. et sp. nov., a worm from the Tremadocian of Shropshire. Quarterly Journal of the Geological Society of London 109, 125-135. DOI 10.1144/GSL.JGS.1953.109.01-04.07

Wills, M.A. 1998. Cambrian and Recent disparity: the picture from priapulids. Paleobiology 24, 177-199.

Wrona, R. 1982. Early Cambrian phosphatic microfossils from southern Spitsbergen (Hornsund Region). Palaeontologia Polonica 43, 9-16.

Wrona, R. 1987. Cambrian microfossil Hadimopanella Gedik 
from glacial erratics in West Antarctica. Palaeontologia Polonica 49, 37-48.

Wrona, R. 2004. Cambrian microfossils from glacial erratics of King George Island, Antarctica. Acta Palaeontologica Polonica 49, 13-56.

Wrona, R. \& Hamdi, B. 2001. Palaeoscolecid sclerites from the Upper Cambrian Mila Formation of the Shahmirzad section, Alborz Mountains, northern Iran. Acta Geologica Polonica 51, 101-107.

Zhang, W., Lu, Y., Zhu, Z, Qian, Y., Lin, H., Zhou, Z., Zhang, S.
\& YuAn, J. 1980. Cambrian trilobite faunas of southwestern China. Palaeontologica Sinica, New Series B 16, 1-497. [in Chinese with English summary]

Zhang, X. \& PRATT, B.R. 1996. Early Cambrian palaeoscolecidan cuticles from Shaanxi, China. Journal of Paleontology 70, 275-279.

Zhang, X., Hou, X. \& Bergström, J. 2006. Early Cambrian priapulid worm buried with their lined burrows. Geological Magazine 143, 743-748.

DOI 10.1017/S0016756806002445 